TAPROBANICA, ISSN 1800-427X. April, 2012. Vol. 04, No. 01: pp. 59.

(C) Taprobanica Private Limited, Jl. Kuricang 18 Gd.9 No.47, Ciputat 15412, Tangerang, Indonesia.

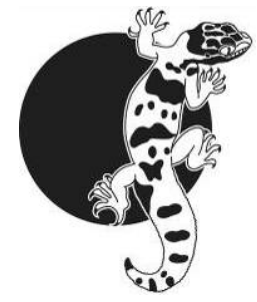

\section{First record of the dollarbird (Eurystomus orientalis) from Colombo District, Sri Lanka}

The Dollarbird, Eurystomus orientalis is one of the rarest (Harrison \& Worfolk, 1999) and endangered (IUCNSL \& MENR, 2007) bird in Sri Lanka. During a pilgrimage to Ambulgala Rajamaha Viharaya on 6 July 2009, one individual of dollarbird (see the cover page of this journal) was

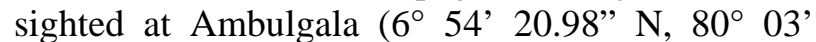
03.01" E) between Hanwella and Ranala around 17:20 h. The dollarbird perched on a branch of a Jack tree (Artocarpus heterophyllus) around $10 \mathrm{~m}$ from ground level. During 40 minutes the bird flew away two times and came back and perched on the same tree. The villagers reported that the bird has been roosting on the same tree for past two months. Dollarbirds have been previously reported from many locations (Fig. 1) (Henry, 1998; Kotagama \& Wijayasinha, 1998; Legge, 1880; Rasmussen \& Anderton, 2005; Seneratne, 1998), but this is the first record from Colombo District, which is $40 \mathrm{~km}$ away from the nearest previous record from Kalutara District, Sri Lanka.

\section{Acknowledgments}

The authors wish to thank L. E. Harding, S. Maduranga, D. Wakagoda, U. Hettige and N. Karunarathna for valuable comments.

\section{Literature cited}

Harrison, J. and T. Worfolk, 1999. A Field Guide to the Birds of Sri Lanka. Oxford University Press Inc, New York, USA: 219.

Henry, G. M., 1998. A Guide to the Birds of Sri Lanka. Hoffmann, T.W., D. Warakagoda and U. Ekanayake, (Eds.) Oxford University Press, New Delhi: 488.

IUCNSL and MENR, 2007. The 2007 National Red List of Threatened Fauna and Flora of Sri Lanka. Colombo, Sri Lanka: 148.

Kotagama, S. and A. Wijayasinha, 1998. Siri Laka Kurullo "Birds of Sri Lanka" (text in Sinhala). Wildlife Heritage Trust of Sri Lanka, Colombo: 394.
Kotagama, S. W., R. I. De Silva, A. S. Wijayasinha and V. Abeygunawardena, 2006. Avifaunal list of Sri Lanka. In: Bambaradeniya, C. N. B (ed.), Fauna of Sri Lanka: Status of Taxonomy, Research and Conservation. IUCN Sri Lanka: 164-203.

Legge, W. V. 1880. A history of the birds of Ceylon. (Reprint), Thisara Prakashakayo, Dehiwala: 638.

Rasmussen, P. C. and J. C. Anderton, 2005. Birds of South Asia: The Ripley Guide - Vols. 1 \& 2. Smithsonian: 378 \& 683.

Seneratna, C. V. 1998. A sight record of Broad-Billed Roller (Dollarbird) Eurystomus orientalis from Trincomalee. Sri Lanka Naturalist, 2 (4): 43-44.

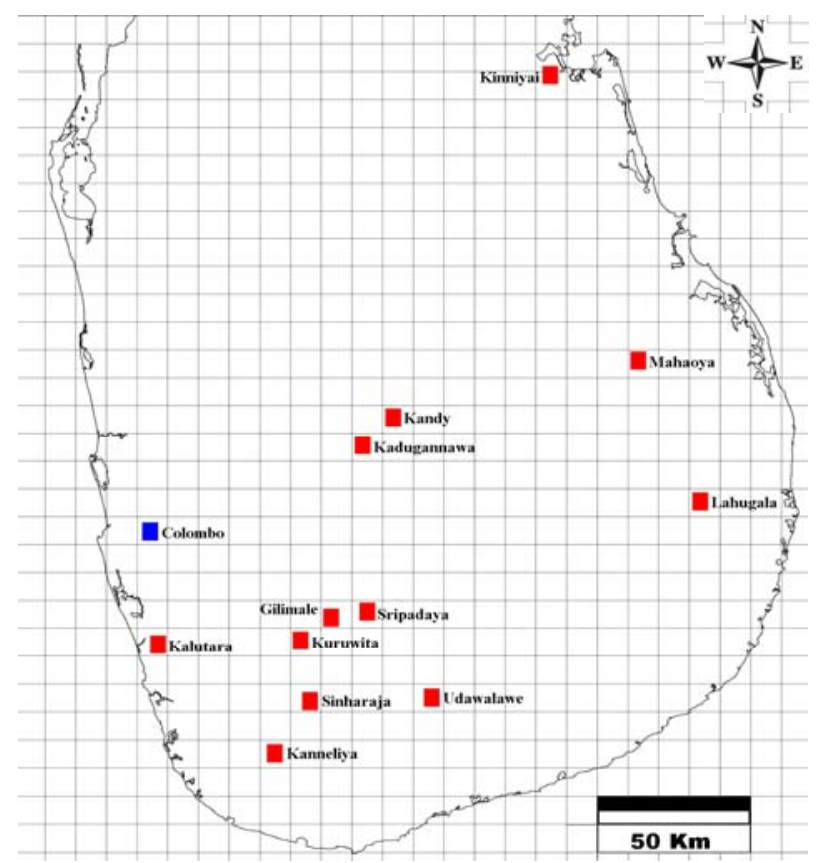

Figure 1: Distribution of the Dollarbird (blue= current record; red= previous records).

D. M. S. S. Karunarathna ${ }^{1,3}$, N. Hapuarachchi ${ }^{2}$, D. H. P. U de Silva ${ }^{1}$, A. Kumarasinghe ${ }^{1}$, U. T. I. Abeyawardene ${ }^{1}$ and M. Madawala ${ }^{1}$

${ }^{1}$ Young Zoologists' Association, Department of National Zoological Gardens, Sri Lanka E-mail: dmsameera@gmail.com ${ }^{3}$

${ }^{2}$ Wildlife Conservation Society, Galle, Sri Lanka 